\title{
Implementation of the Active Learning Model Type of Role Reversal Question to Improve Student Learning Outcomes
}

\author{
Siti Khotimah ${ }^{1}$, Saiful Amin ${ }^{2,3, *}$, Yeny Irawati ${ }^{2}$, Wahdaniyah Azizah Putri \\ Ayuningtyas $^{2}$ \\ ${ }^{1}$ UPT Sekolah Dasar Negeri Wlingi 3 Blitar, Indonesia \\ ${ }^{2}$ Department of Social Science Education, Universitas Islam Negeri Maulana Malik Ibrahim Malang, Indonesia \\ ${ }^{3}$ Doctoral Student at Department of Geography Education, Universitas Negeri Malang, Indonesia \\ ${ }^{*}$ Corresponding author. Email: amin.geo87@pips.uin-malang.ac.id

\begin{abstract}
This study aims to describe the improvement of Civics learning outcomes by using the active learning model with the role reversal question type for fifth-grade students of SD Negeri Tangkil 03 Wlingi. This type of research is classroom action research. The research subjects were students of class V SD Negeri Tangkil 03 Blitar, totaling 14 students. Methods of data collection in this study using tests, observation, and documentation. The research instruments were tests and observation sheets. Data analysis techniques used are descriptive quantitative, and qualitative. The success of the action is marked by $\geq 75 \%$ of the number of students who take part in the learning process who have obtained a value of $\geq 70$. The results showed an increase in Civics learning outcomes for fifth-grade students of SD Negeri Tangkil 03 Blitar after using the active learning model role-reversal question in cycle I and cycle II. Students who scored $\geq 70$ experienced an increase of $21 \%$ in the first cycle, with the initial condition of $43 \%$ increasing to $64 \%$. There was an increase of $29 \%$ in the second cycle, from $64 \%$ to $93 \%$. Based on the study results, there are several suggestions; first, teachers are expected to use the active learning model type role-reversal question to improve student learning outcomes. Second, it is hoped that further researchers can develop an active learning model of role reversal question in different subjects and pay more attention to student activities when exchanging roles.
\end{abstract}

Keywords: Active learning model, type role reversal question, student learning outcomes

\section{INTRODUCTION}

Citizenship Education (Civics) is a social science subject required for primary, secondary, and compulsory courses for higher education [1]. Civics lessons taught at the elementary school level focus on real objects and events in the future, referred to as concrete operations [2]. This opinion is in line with [3] that most elementary school children in substantial operations are less able to think abstractly. Based on elementary school-aged children's thoughts and characteristics, the teacher can plan activities containing direct student involvement elements in implementing Civics learning.

In fact, in the civics learning process in elementary schools, students have not been fully involved directly, as happened in class V SD Negeri Tangkil 03 Wlingi. The learning activities are dominated by teacher activities, namely by using the lecture method when explaining the subject matter. Based on observations made when Civics learning activities were taking place, students did not fully pay attention to the teacher's explanation because they were bored with listening activities, so that Civics learning was less enjoyable for students.

The motivation of the fifth-grade students of SD Negeri Tangkil 03 Wlingi in participating in low Civics learning was seen when the learning activities took place. Some students made much noise. The teacher repeatedly conditions the rowdy students to be quiet and pay attention to learning, but this is ignored. Apart from making noise when learning Civics, some students did not do their assignments seriously. When finished explaining knowledge, the teacher gives students tasks to do the questions, but many students do it carelessly 
because they do not want to read books to answer questions.

This situation causes the acquisition of learning outcomes that are not optimal. Civics' poor learning outcomes can be seen from the first semester of the 2016/2017 academic year. The average Civics score is lower than the scores for Indonesian and social studies. It has been known that the average Indonesian language score is 74, Social Studies 68, and Civics 66. In addition to the low Civics average score, data obtained that only 18 students or $50 \%$ of the total students have not met the specified KKM, namely 65 . Seeing the number of students who still Many get scores below the completeness criteria and the average Civics value that has not been maximal, it is necessary to improve Civics learning outcomes.

The way that teachers can take to improve learning activities is by using the active learning model. Active learning is a learning model that refers to learning objectives involving students, using art, movement, and the five senses and steps and activities in learning [4], [5]. In line with this, active learning is a learning process that focuses on student activities, both physical, mental, emotional, and intellectual, to achieve educational goals related to cognitive, affective, and psychomotor aspects [6], [7]. Based on this statement, it can be concluded that active learning is a learning activity that activates students because students are directly involved in learning related to cognitive, affective, and psychomotor aspects.

The active learning model has advantages in learning. The advantages, namely 1) students are actively involved in learning activities; 2) students use all their potential in the learning process; 3 ) the use of the active learning model makes student-centered learning not teachercentered, and 4) the active learning model can foster students' attitudes to be able to think critically about the material being studied [8].

Various active learning types emphasize question and answer activities; the name starts with an item, role reversal questions, and planted questions [9], [10]. Question and answer activities can help students to gain knowledge, skills, and activity in learning. It is by research conducted by [11] that active learning starts with a question in which Civics learning can increase students' questioning activities.

In this study, active learning is also used to emphasize question and answer activities, but there is a difference, namely, using a role reversal question. The application of role reversal questions is by asking questions and exchanging roles [12]. Doing questions and answers can make it easier for students to understand the material, make students active, and improve learning outcomes [13]. The active learning model type rolereversal question applied in Civics learning can activate students, especially in question and answer activities, by exchanging roles [14], [15]. Students can participate directly, listen to the explanation of the teacher's material, and think critically in question and answer about the learning material being studied [16]. The active learning model role-reversal question in elementary schools is expected to understand the material being studied to increase student learning outcomes. This study aims to implement an active learning model type rolereversal question that can improve elementary school students' civic learning outcomes.

\section{METHOD}

This research is a classroom action research, an examination of learning activities in deliberately raised actions and occurs in a class together [17]. The research stages in this classroom action research consist of four stages: first, planning, where the researcher plans the activities to be carried out to overcome the problems based on initial observations. Second, implementation, that is, the researcher carries out the learning activities according to the Learning Implementation Plan (RPP) that has been previously planned. Third, observation, which carried out to observe the course of active learning model type role-reversal question based on the activity observation sheet that has been prepared. Fourth, reflection aims to examine the implementation of learning, which is used as a reference for making improvement plans in the next cycle.

The subjects in this study were fifth-grade students of SD Negeri Tangkil 03 Wlingi, Blitar. The number of research subjects was 14 students, consisting of 9 boys and five girls. Students who are research subjects follow Civics subjects with Basic Competencies (KD): 1) 3.2. Citing examples of organizations in the school and community environment, and 2) 3.3. Show participation in selecting organizations in schools.

The data collection instruments used included: 1) tests, in the form of a written test with an objective form (multiple choice) totaling 20 questions; 2) observation sheet, using systematic observation with pre-designed observation instruments; and 3) documentation, in the form of teacher and student observation sheets, a list of values, and lesson plans used in the application of the role reversal question type active learning model.

This classroom action research uses quantitative and qualitative analysis - obtained from learning outcomes. Learning outcomes were obtained through tests carried out at the end of the cycle in Civics learning activities using the active learning model type role-reversal question. The statistical formula used to process student learning outcomes uses the class average score formula [18]. 


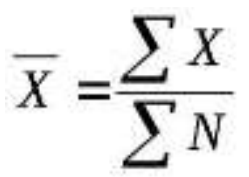

Information:

$\overline{\mathrm{X}}=$ average score

$\sum \mathrm{X}=$ total student score

$\sum \mathrm{N}=$ number of students

To calculate the percentage of student learning outcomes using the following formula.

Persentase $(\%)=\frac{\text { Jumlah skor yang diperoleh }}{\text { Jumlah skor maksimal }} \times 100 \%$

The student learning outcomes are interpreted in the following criteria shown in table 1.

Table 1. Criteria for learning outcomes

\begin{tabular}{|c|c|}
\hline Value & Criteria \\
\hline $80-100$ & Very Good \\
\hline $70-79$ & Good \\
\hline $60-69$ & Enough \\
\hline $50-59$ & Less \\
\hline $0-49$ & Very Less \\
\hline
\end{tabular}

The active learning model type role-reversal question has succeeded in improving Civics learning outcomes in class V SD Negeri Tangkil 03 Wlingi if $\geq 75 \%$ of the total students get an average value $=\geq 70$ [19].

This study's qualitative data analysis was obtained from the results of observations analyzed descriptively to receive data regarding teachers' and students' activities in participating in Civics learning using the role reversal question type active learning model.

\section{RESULTS}

\subsection{Data on Learning Outcomes Pre-Action}

Before carrying out the research activities, the researcher first carried out the pre-action stage in observations about Civics learning activities in class V SD Negeri Tangkil 03 Wlingi. This activity was carried out to determine an initial description of student activities when Civics learning was delivered. From the observations, it is known that learning activities are still teacher-centered. The more dominant teacher activities evidence during Civics learning.

From Civics learning activities applied to class V has an impact on student learning outcomes. The description of the initial conditions supported by the provision of preaction in the form of Civics questions given to 14 students of class V SD Negeri Tangkil 03. Student learning outcomes in pre-action can be grouped based on the range of values. Pre-action value grouping for more details can be seen in table 2 .

Table 2. Classification student values in pre-action

\begin{tabular}{|c|c|c|c|}
\hline Value & Criteria & $\begin{array}{r}\text { Total of } \\
\text { Student }\end{array}$ & Percentage \\
\hline $0-49$ & Very Good & 1 & $7.14 \%$ \\
\hline $50-59$ & Good & 2 & $14.29 \%$ \\
\hline $60-69$ & Enough & 5 & $35.71 \%$ \\
\hline $70-79$ & Less & 5 & $35.71 \%$ \\
\hline $80-100$ & Very Less & 1 & $7.14 \%$ \\
\hline
\end{tabular}

Table 2 shows that students who get $0-49$ or very poor criteria are one student. Students who earn a score of 50-59 are less than two students, of 60-69 or on sufficient criteria are five students. Students who get a score of 70-79 or on the right criteria are five students. In contrast, the value of 85-100 or the excellent criteria amounted to 1 student. Based on the grouping of student scores in the pre-action, learning outcomes are obtained, as shown in table 3.

Table 3 Student learning outcomes in pre-action

\begin{tabular}{|c|c|c|}
\hline No. & Value & Pre-Action \\
\hline 1. & $\geq 70$ & $43 \%$ \\
\hline 2. & $<70$ & $57 \%$ \\
\hline
\end{tabular}

Based on table 3, it is known that of the total new students, there are six students or $43 \%$ of the total students who scored $\geq 70$. Eight students, or $57 \%$ of the total students, scored $<70$. The mean score of students in the pre-action was $57 \%$. This data shows that $75 \%$ of the total students have not received a score of $\geq 70$; this is still far from the expected target.

Based on the observations and pre-actions that have been carried out on the Civics learning process, a plan to improve the learning process using the active learning model type role-reversal question is compiled so that it is expected to enhance Civics learning outcomes in class V SD Negeri Tangkil 03 Wlingi.

\subsection{Data on Learning Outcomes in Cycle I Action}

Learning outcomes were obtained from tests conducted at the end of each cycle. The data obtained were in the form of numbers regarding the value obtained by each student on the questions that were carried out after applying the active learning model type role reversal question in the Civics learning process. The items given in this test are 20 multiple-choice questions. Student learning outcomes in 
cycle I can be grouped based on the range of values. Grouping student scores in the circle I for more details can be seen in table 4 .

Table 4 Classification of student values in cycle I

\begin{tabular}{|c|c|c|c|}
\hline Value & Criteria & $\begin{array}{c}\text { Total of } \\
\text { Student }\end{array}$ & Percentage \\
\hline $0-49$ & Very Good & 0 & 0 \\
\hline $50-59$ & Good & 2 & $14 \%$ \\
\hline $60-69$ & Enough & 3 & $21 \%$ \\
\hline $70-79$ & Less & 2 & $14 \%$ \\
\hline $80-100$ & Very Less & 7 & $50 \%$ \\
\hline
\end{tabular}

Based on table 4 , there are no students who get a score of 0-49. Students who get a score of 50-59 or the criteria are less than two students. 3 students obtain students who score 60-69 or on sufficient criteria. Students who get a score of 70-79 or on the right criteria are two students. In contrast, the value of 85-100 or the excellent criteria totaled seven students. Based on the amounts above, the student learning outcomes in the cycle I obtained can be seen in table 5.

Table 5. Student learning outcomes in cycle I

\begin{tabular}{|c|c|c|}
\hline No. & Value & Cycle I \\
\hline 1. & $\geq 70$ & $64 \%$ \\
\hline 2. & $<70$ & $36 \%$ \\
\hline
\end{tabular}

Based on cycle I, there was nine students or $64 \%$ of the total students who got $\geq 70$. In contrast, five students or $36 \%$ of the total students scored $<70$. Based on these data, it can be obtained that student learning outcomes in the cycle can be seen in Table 6 and Figure 1.

Table 6. Achievements of student learning outcomes in cycle I

\begin{tabular}{|c|c|c|c|c|}
\hline \multirow{2}{*}{ Value } & \multicolumn{2}{|c|}{ Pre-Action } & \multicolumn{2}{c|}{ Cycle I } \\
\cline { 2 - 5 } & Frequency & $\boldsymbol{\%}$ & Frequency & $\%$ \\
\hline$\geq 70$ & 16 & 43 & 9 & 64 \\
\hline$<70$ & 20 & 57 & 5 & 36 \\
\hline
\end{tabular}

This data shows that Civics learning using the active learning model type role-reversal question for fifth-grade students of SD Negeri Tangkil 03 Wlingi can improve learning outcomes. The number of students who scored $\geq 70$ experienced an increase, namely by $21 \%$, from the initial condition of $43 \%$, increasing to $64 \%$.

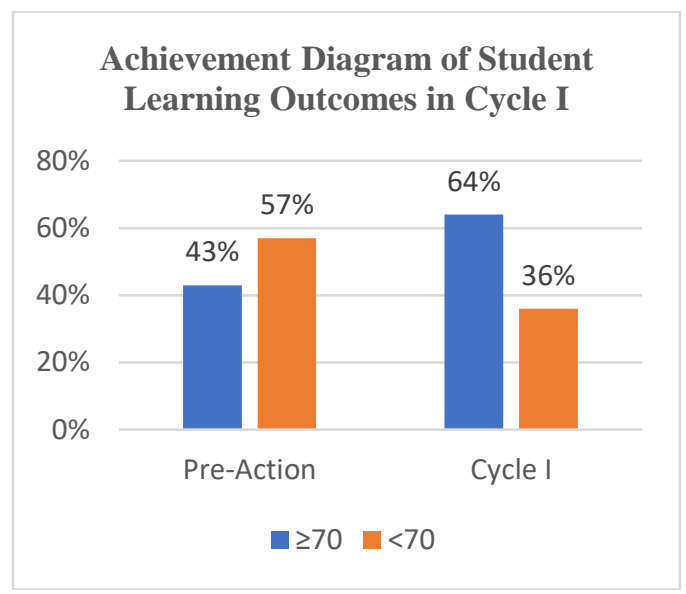

Figure 1. Achievement diagram of student learning outcomes in cycle I

\subsection{Data on Learning Outcomes in Cycle II Action}

Learning outcomes were obtained from tests conducted at the end of each cycle. The data obtained were in the form of numbers regarding the value obtained by each student on the questions that were carried out after applying the active learning model type role reversal question in the Civics learning process. Student learning outcomes in cycle II can be grouped based on the range of values. Grouping student scores in cycle II for more details can be seen in table 7 .

Table 7. Classification of student values in cycle II

\begin{tabular}{|c|c|c|c|}
\hline Value & Criteria & $\begin{array}{c}\text { Total of } \\
\text { Student }\end{array}$ & Percentage \\
\hline $0-49$ & Very Good & 0 & 0 \\
\hline $50-59$ & Good & 0 & 0 \\
\hline $60-69$ & Enough & 1 & $2.78 \%$ \\
\hline $70-79$ & Less & 6 & $16.67 \%$ \\
\hline $80-100$ & Very Less & 7 & $50 \%$ \\
\hline
\end{tabular}

Table 7 shows that none of the students scored 0-59. Students who get a score of 60-69 or on sufficient criteria amount to 1 student. Students who score $70-79$ or on the right criteria are six students. In contrast, the value of 85100 or the very good criteria totaled seven students. Based on the values above, the student learning outcomes in cycle II are obtained, as shown in table 8 .

Table 8. Student learning outcomes in cycle II

\begin{tabular}{|c|c|c|}
\hline No. & Value & Cycle II \\
\hline 1. & $\geq 70$ & $93 \%$ \\
\hline 2. & $<70$ & $7 \%$ \\
\hline
\end{tabular}


Based on table 8 , it is known that as many as 13 students, or $93 \%$ of the total students, scored $\geq 70$. Furthermore, one student or $7 \%$ of the total students scored $<70$. Based on these data, it can be obtained the student learning outcomes in cycle II, which can be seen in Table 9 and Figure 2.

Table 9. Achievements of student learning outcomes in cycle II

\begin{tabular}{|c|c|c|c|c|c|c|}
\hline \multirow{2}{*}{ Value } & \multicolumn{2}{|c|}{ Pre-Action } & \multicolumn{2}{c|}{ Cycle I } & \multicolumn{2}{c|}{ Cycle II } \\
\cline { 2 - 7 } & Frequency & $\%$ & Frequency & $\%$ & Frequency & $\%$ \\
\hline$\geq 70$ & 16 & 43 & 9 & 64 & 13 & 93 \\
\hline$<70$ & 20 & 57 & 5 & 36 & 1 & 7 \\
\hline
\end{tabular}

Learning outcomes in pre-action that have increased in cycle I, rose again in cycle II. The number of students who scored $\geq 70$ increased by $21 \%$ from the initial condition of $43 \%$ to $64 \%$ in cycle I, then increased again by $29 \%$ to $93 \%$ in cycle II.

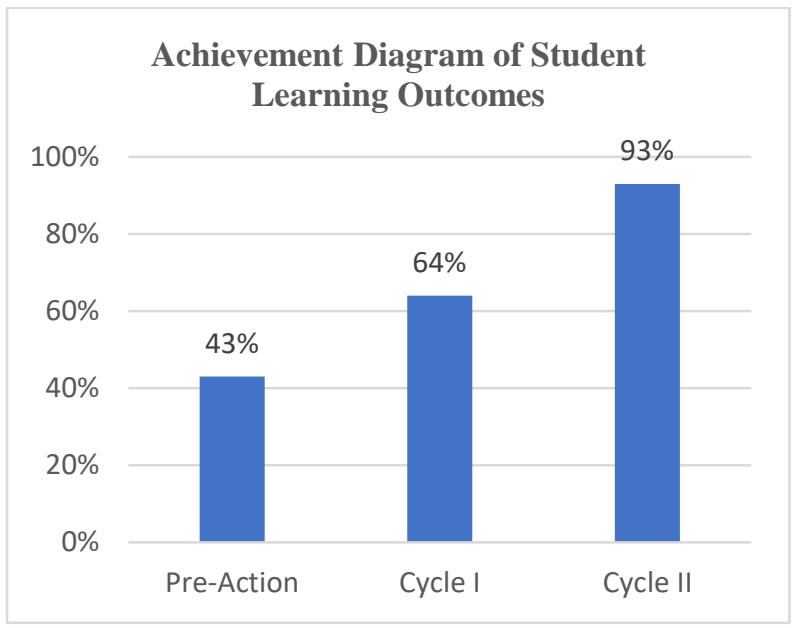

Figure 2. Achievement diagram of student learning outcomes in cycle II

\section{DISCUSSION}

In the pre-action stage, 14 students scored $\geq 70$, or 6 students or $43 \%$, while 8 students, or $57 \%$ scored $<70$. It shows that Civics subjects' student learning outcomes at SD Negeri Tangkil 03 Wlingi are still far from the expected target. For this reason, researchers feel the need to conduct action research to improve learning outcomes that are not yet in line with expectations. Seeing this, the researchers tried to improve civics learning outcomes in class V SD Negeri Tangkil 03 Wlingi by using the active learning model type role-reversal question.

In cycle I, there was an increase. The number of students who scored $\geq 70$ increased by $21 \%$ from the initial condition of $43 \%$ to $64 \%$. It proves that the actions in the cycle I influence student learning outcomes in Civics subjects.

The increase in student learning outcomes in cycle I was caused by the teacher's active learning model type rolereversal question. The active learning model type rolereversal question emphasizes question and answer activity by exchanging roles [20]. The learning implementation is modified by considering the abilities and needs of students. The learning activity begins with the teacher explaining a series of learning activities, including the question and answers rules by exchanging roles. The teacher divides students into groups to carry out discussions about the subject matter. The activity continued by making individual questions so that the problems that arise are by the material being studied. After students make personal questions, the next activity is questions and answers by exchanging roles. The teacher provides feedback on student answers.

Implementing Civics learning by applying the active learning model type role-reversal question in cycle I have gone well. However, some deficiencies need to be fixed, namely the teacher's activities in explaining students' learning activities and the low action of answering questions. Based on the observations in cycle I, the teacher's first meeting did not explain learning activities such as discussions, making individual questions, and exchanging roles for questions and answers at the beginning of the learning activity, but when students held group discussions. After doing the perception, the teacher immediately divided the students into groups. While the debate is ongoing, the new teacher explains the learning activities that will be carried out. It makes the course of learning unconditional. When conducting group discussions, students must listen to the teacher's explanation. Some students did not listen to the teacher's explanation, so they continued other activities every time. The teacher explained the learning activities to be carried out.

The constraints that appeared in cycle I was corrected in cycle II. In cycle II the teacher explains learning activities according to the learning implementation plan, namely at the beginning of the activity. After the students understood, the next activity was carried out. The teacher always guides and directs students in learning activities. The teacher also provides encouragement and motivation for students to be active in learning. Sugihartono's [21] opinion is that one of the teacher's roles in learning activities is as a motivator. As a motivator, teachers must encourage their students to have high motivation and be active in learning. In this case, the teacher provides encouragement and inspiration to dare to ask questions and answer questions during the question and answer activity. Students who have never answered the questions are given many opportunities so that none is dominant in answering the questions.

The implementation of learning activities in cycle II that was carried out by the teacher was better than in cycle I. 
The teacher had implemented and organized Civics learning using the active learning model type rolereversal question better. Student activities in learning are more conditioned and sequential by the lesson plan. All students are engaged in learning activities.

The results of students' observations in cycle II showed that students were more active, happy, and excited about participating in learning. After students listened to the teacher's explanation of the activities carried out, students immediately took the initiative to gather with their respective groups to discuss and write down the discussion results correctly on the prepared discussion sheet. After finishing the discussion, the students immediately asked for sheets to make individual questions and were very enthusiastic about doing questions and answers by exchanging roles. Students competed to get the most rewards during the question and answer session by exchanging teacher roles and giving rewards to students who answered the questions correctly. Students who gave questions were also given verbal rewards so that other students were motivated to ask questions. Students who have not answered the questions correctly are not blamed by the teacher but are explained the correct answers. Students are also allowed to answer other questions and are still motivated to remain courageous in answering questions.

In the second meeting cycle, there were additional activities after conducting group discussions, namely simulating class leaders' selection. After discussing ways to choose class leaders, students are guided by the teacher to learn to simulate the selection of class leaders by direct voting. There are 2 prospective class leaders, then the students vote by pointing their fingers, provided that who gets the most votes becomes the chairman. The next activity students are assigned to make questions and exchange roles for question and answer. In the rotation activity, the enthusiasm of students to get the reward was very high, every time there were questions from both teachers and students, almost all students raised their fingers to answer. When students become teachers, students give questions but the teacher does not immediately answer, this is done to provide opportunities for other students to answer questions, and the teacher provides reinforcement for students' answers. Like cycle I, at the end of Cycle II's second meeting, an evaluation was carried out to see an increase in student learning outcomes.

Student learning outcomes after-action improvements in cycle II increased significantly from pre-action, cycle I, and cycle II. Students who scored $\geq 70$ increased $21 \%$ from the initial conditions of $43 \%$ to $64 \%$ in cycle I and increased $29 \%$ again to $93 \%$ in cycle II. Thus the second cycle has reached the specified success criteria of action, namely $75 \%$ of the total students get a value of $\geq 70$, so the research stopped in cycle II.

The increase in cycle I and cycle II was inseparable from teachers who had implemented the active learning model type role-reversal question in Civics subjects. The active learning model's characteristics are that learning activities emphasize student learning activities, and learning is passive. Students listen to teacher Hamid's explanation [22]. Learning activities are more dominated by student activities in gaining direct learning experience with teacher guidance [23]. Ibrahim and Sukmadinata [24] assert that teachers should plan teaching that demands student activity in learning. By applying the active learning model type role-reversal question, students are engaged in learning and fostered to have smart, skilled, critical, creative thinking [25]. It is in line with Civics' objectives and functions, which are contained in Permendikbud No. 21 of 2016 concerning Content Standards for Primary and Secondary Education [26].

\section{CONCLUSION}

Based on the results of research and discussion, it can be concluded that the implementation of the active learning model type role-reversal question can improve the learning outcomes of fifth-grade students of SD Negeri Tangkil 03 Wlingi, Blitar. It is shown by students who scored $\geq 70$ in the first cycle increased by $21 \%$ from the initial conditions of $43 \%$ to $64 \%$. Students who got a score of $\geq 70$ in cycle II experienced an increase of $29 \%$ to $93 \%$. The steps for the active learning model type rolereversal question include: 1) the teacher makes questions according to the material before learning activities begin; 2) explain learning activities; 3 ) dividing students into groups; 4) assigning students to conduct group discussions; 5) assigning students to make individual questions, 6) doing questions and answers by changing roles; and 7) provide feedback on students' responses. Based on the study results, there are several suggestions; first, teachers are expected to use the active learning model type role-reversal question to improve student learning outcomes. Second, it is hoped that further researchers can develop an active learning model of role reversal question in different subjects and pay more attention to student activities when exchanging roles.

\section{ACKNOWLEDGMENT}

Our gratitude goes to the Blitar Regency Education Office, UPT SDN Tangkil 3 Wlingi Blitar, students, and all parties participating in this research.

\section{REFERENCES}

[1] Kemdikbud, "Undang-Undang Republik Indonesia Nomor 20 tahun 2003 Tentang Sistem Pendidikan Nasional." Kementerian Pendidikan Dan Kebudayaan, 2003. 
[2] R. A. Juwantara, "Analisis Teori Perkembangan Kognitif Piaget pada Tahap Anak Usia Operasional Konkret 7-12 Tahun dalam Pembelajaran Matematika," AAPGMI, vol. 9, no. 1, p. 27, Jun. 2019, doi: 10.18592/aladzkapgmi.v9i1.3011.

[3] S. E. W. Djiwandono, Psikologi Pendidikan. Jakarta: Grasindo Gramedia Widiasarana Indonesia, 2002.

[4] P. Hollingsworth and G. Lewis, "Active Learning: Increasing Flow in the Classroom," Education Review, vol. 0, no. 0, art. no. 0, 2006, doi: 10.14507/er.v0.686

[5] A. Samandhi, Pembelajaran Aktif (Active learning). Jakarta: Teaching Improvement Workshop, Engineering Education Development Project, 2009.

[6] N. Lailah, "Konsep Dasar Active Learning Dan Relevansinya Dengan Pengajaran Muhadatsah," Skripsi, UIN Sunan Kalijaga, Yogyakarta, 2003.

[7] A. Srinath, "Active Learning Strategies: An illustrative approach to bring out better learning outcomes from Science, Technology, Engineering and Mathematics (STEM) students," International Journal of Emerging Technologies in Learning (iJET), vol. 9, no. 9, Art. No. 9, Oct. 2014.

[8] M. Arif and Rohana, "Meningkatkan Hasil Belajar Pkn Melalui Model Pembelajaran Active Learning Tipe Role Reversal Question Di Kelas VII2 SMPN 1 Gunung Tuleh," Jurnal Kepemimpinan dan Pengurusan Sekolah, vol. 3, no. 1, pp. 65-80, Mar. 2018, doi: 10.34125/kp.v3i1.250.

[9] S. I. Friedland, "Role Reversal: Letting Students Ask the Questions in a Criminal Law Class," Ohio St. J. Crim. L., vol. 10, p. 651, 20132012.

[10] M. L. Silberman, Active learning: 101 strategies to teach any subject. Boston: Allyn and Bacon, 1996.

[11] A. Karoni, "Pembelajaran Active learning Starts with a Question untuk meningkatkan keaktifan bertanya siswa dalam pembelajaran PKn kelas IV MIM Sraten, Sukoharjo Tahun Ajaran 2010/2011," Undergraduate Thesis, UIN Sunan Kalijaga, Yogyakarta, 2011.
[12] M. Barnes, Role Reversal: Achieving Uncommonly Excellent Results in the StudentCentered Classroom. Alexandria, Va: ASCD, 2013.

[13] B. Chang, F.-Y. Yu, Y.-Y., Chen and H.-T. Hsieh, "Thinking From An Opposing Position: A Framework For A Role-Reversal Pedagogy Using Technology," Research and Practice in Technology Enhanced Learning, vol. 8, no. 3, pp. 347-362, 2013.

[14] T. Santoso, "Peningkatan Hasil Belajar Ppkn Menggunakan Model Active Learning Tipe Role Reversal Question Pada Peserta Didik Kelas V SPF SDN Pringapus 03," Waspada (Jurnal Wawasan Pengembangan Pendidikan), vol. 7, no. 1, Art. no. 1, May 2020.

[15] Usri, "Upaya Meningkatkan Hasil Belajar Pkn Menggunakan Model Active Learning Tipe Role Reversal Question Pada Siswa Kelas VI SD Negeri 020 Pangkalan Baru Kecamatan Siak Hulu," JURNAL PAJAR (Pendidikan dan Pengajaran), vol. 2, no. 6, Art. no. 6, Nov. 2018 , doi: $10.33578 /$ pjr.v2i6.6540.

[16] D. Siregar, "Upaya Meningkatkan Hasil Belajar PKN Menggunakan Model Active Learning Tipe Role Reversal Question Pada Siswa Kelas V Di SD Negeri 060898 Medan," ESJ, vol. 7, no. 4, pp. 520-527, Dec. 2017, doi: 10.24114/esjpgsd.v7i4.10320.

[17] Sugiyono, Metode Penelitian Kuantitatif Kualitatif dan R\&D. Bandung: Alfabeta, 2011.

[18] S. Arikunto, Prosedur Penelitian: Suatu Pendekatan Praktik, 14th ed. Jakarta: Rineka Cipta, 2010.

[19] B. Kartowagiran, "Dasar-Dasar Penelitian Tindakan,” p. 22, 2005.

[20] S. Aminah, "Penggunaan Model Active Learning Tipe Role Reversal Question pada Siswa SD Negeri 007 Sungai Kubu Rokan Hilir," Serambi PTK, vol. 4, no. 2, Art. no. 2, Nov. 2017.

[21] dkk Sugihartono, Psikologi Pendidikan. Yogyakarta: UNY Press, 2007.

[22] M. S. Hamid, Metode Edutainment. Yogyakarta: Diva Press, 2012. 
[23] A. S. Murti, "Peningkatkan Hasil Belajar PKN Kelas V Melalui Model Active Learning (Tipe Role Reversal Question) SDN 4 Doplang Kecamatan Jati Kabupaten Blora," Premiere Educandum: Jurnal Pendidikan Dasar dan Pembelajaran, vol. 6, no. 02, Art. no. 02, Dec. 2016, doi: 10.25273/pe.v6i02.811.

[24] R. Ibrahim and N. S. Sukmadinata, Perencanaan Pengajaran. Jakarta: Rineka Cipta, 2010.

[25] G. Diputra and S. Rokhana, "Upaya Meningkatkan Hasil Belajar PKn Menggunakan Model Active Learning Tipe Role Reversal Question pada Siswa Kelas V SDN 1 Tamanrejo Kabupaten Blora," ELSE (Elementary School Education Journal): Jurnal Pendidikan dan Pembelajaran Sekolah Dasar, vol. 3, no. 1, Art. no. 1, Feb. 2019, doi: http://dx.doi.org/10.30651/else.v3i1.2413.
[26] Kemdikbud, "Permendikbud No 21 Tahun 2016 Tentang Standar Isi Pendidikan Dasar dan Menengah." Kementerian Pendidikan Dan Kebudayaan, 2016, Accessed: Sep. 15, 2020. [Online]. Available: https://bsnpindonesia.org/standar-isi/. 